\title{
Analisis Proporsi Anggaran Belanja Pembangunan Dan Anggaran Belanja Rutin Terhadap Pertumbuhan Ekonomi Kabupaten Lombok Tengah Tahun 2012-2016
}

\section{Siti Fatimah.}

Universitas Mataram

\begin{tabular}{l}
\hline A R TICLE INFO \\
\hline Keywords: \\
Development Expenditure \\
and Routine Expenditure
\end{tabular}

Kata Kunci :

Belanja Pembangunan dan

Belanja Rutin.

Received : 9 Juni 2018; Accepted: 18 Juli 2018; Published: September 2018

ABSTRACT : In the line with the flow of authority which more widely owned by every
region in this era of regional autonomy so the rule and function of the regional
incometrough the extracting potential of each region become a very important, the
perspective regional autonomy which is related with the economic growth could be
seen from many aspect such as development expenditure allocation, routine
expenditure allocation and other expenditures, the research aim is to find out the
effect of development expenditure and routine expenditure toward PDRB growth rate
in central Lombok district year of 2012-2016, the proposed hypothesis is suspected that
development expenditure and routine expenditure have an effect toward the growth
rate in central Lombok district year of 2012-2016 which relatively is not too significant,
this is descriptive research, data collecting technique use library study and field
research variable done by regional income (PD), locally generated revenue (PAD)
apparatus expenditure (BA), public expenditure (BP), regional expenditure (BD),
regional revenue and expenditure budget (APBD), product domestic regional bruto
(PDRB), while analysis model use development budget proportions toward economic
regional growth and routine expenditure ratio on economic regional growth also
growth analysis contribution of each expenditure either development expenditure or
routine expenditure, research result shows the average growth rate for five years since
2012-2016 that the growth development expenditure contribution toward PDRB
growth in central Lombok district is $11,79 \%$ while for routine expenditure for five
years since 2012-2016 the contribution growth rate toward PDRB growth rate in
central Lombok district is 7,50\% that smaller compared with development expenditure
contribution which means is not significant.

ABSTRAK : Sejalan dengan arus pemberian kewenangan yang makin luas yang dimiliki tiap daerah dalam era otonomi daerah ini, maka peran dan fungsi pendapatan daerah melalui penggalian potensi masing-masing daerah menjadi sesuatu yang amat penting. Proporsi dana Pembangunan dan dana rutin menjadi sangat strategis dalam mendorong laju pertumbuhan ekonomi suatu daerah.Tujuan penelitian ini adalah untuk melihat bagaimana proporsi dana pembangunan dan dana rutin yang dikaitkan dengan laju percepatan pertumbuhan ekonomi Kabupaten Lombok Tengah terhitung sejak Tahun 2012-2016. Menurut tingkat eksplanasinya jenis penelitian ini termasuk penelitian deskriptif. Teknik pengumpulan data menggunakan studi kepustakaan (Library Research) dan penelitian lapangan (Field Research). Variabel yang digunakan dalam penelitian ini adalah Pendapatan Daerah, Anggaran Pembangunan, Anggaran rutin, Pendapatan lain Yang Syah, Belanja Aparatur, Belanja Pelayanan Publik dan Belanja Bagi Hasil. Adapun alat analisis yang digunakan dalam penelitian ini menggunakan pendekatan rasio dengan membandingkan besarnya Anggaran dana pembangunan dan Anggaran Rutin,pendapatan daerah serta pendekatan PDRB (Product Domestic Ragional Brutto) serta komponen lainnya yang langsung terkait dengan laju pertumbuhan ekonomi kabupaten Lombok Tengah. Hasilnya adalah Dampak pengalokasian dana pembangunan terhadap laju percepatan pertumbuhan ekonomi Kabupaten Lombok Tengahterhitung sejak Tahun 2012-2016 sangat besar. Rata-rata Laju pertumbuhan Kontribusi Dana Pembangunan Terhadap Pertumbuhan Ekonomi (PDRB) Atas Dasar Harga Konstan Tahun 2010 Kabupaten Lombok Tengah 


\begin{tabular}{|c|c|}
\hline & $\begin{array}{l}\text { Tahun } 2012-2016 \text { sebesar } 9,85 \text { persen dan Atas Dasar Harga Berlaku sebesar } 11,79 \\
\text { persen. Artinya bahwa kontribusi dana pembangunan terhadap laju pertumbuhan } \\
\text { ekonomi selama lima tahun di kabupaten Lombok Tengah cukup signifikan, demikian } \\
\text { pula dengan Rata-rata Laju pertumbuhan Kontribusi Dana Anggaran Rutin Terhadap } \\
\text { Pertumbuhan Ekonomi (PDRB) Atas Dasar Harga Konstan Tahun } 2010 \text { Kabupaten } \\
\text { Lombok Tengah Tahun } 2012-2016 \text { sebesar 7,50 persen dan Atas Dasar Harga Berlaku } \\
\text { sebesar 9,36 persen. Artinya bahwa kontribusi dana anggaran rutin terhadap laju } \\
\text { pertumbuhan ekonomi selama lima tahun di kabupaten Lombok Tengah tidak } \\
\text { signifikan. }\end{array}$ \\
\hline $\begin{array}{l}\text { Corresponding Author: } \\
\text { Alamat : Program Studi Ekonom } \\
62 \text { Mataram. } \\
\text { e-mail: sitifatimah@unram.ac.ic }\end{array}$ & $\begin{array}{l}\text { ni Pembangunan, Fakultas Ekonomi dan Bisnis, Universitas Mataram, Jln. Majapahit No. } \\
\text { id }\end{array}$ \\
\hline
\end{tabular}

2018, EKONOBIS All right reserved 


\section{PENDAHULUAN}

\section{Latar Belakang}

Penyelenggaraan pemerintah daerah sebagai sub sitem pemerintahan negara dimaksudkan untuk meningkatkan efektifitas dan efisiensi penyelenggaraan pemerintahan dan pelayanan masyarakat sesuai yang tertuang dalam Undang-undang nomor : 25 Tahun 1999. Peranan dan kemampuan pemerintah daerah dalam pembangunan nasional diupayakan agar bertambah besar. Seiring dengan telah diberlakukannya UndangUndang Nomor : 32/2004 tentang Pemerintahan Daerah dan Undang-Undang Nomor : 33/2004 tentang Perimbangan Keuangan Antara Pemerintah Pusat dan Daerah, maka terhitung sejak itulah kewenangan pemerintah daerah semakin besar untuk mengatur rumah tangganya sendiri. Melalui otonomi daerah yang telah dituangkan dalam peraturan perundangundangan telah menimbulkan dampak yang cukup luas terhadap kewenangan pemerintah daerah termasuk perimbangan keuangan pusat dan daerah.

Secara nyata ketentuan-ketentuan di atas telah membawa daerah menjadi otonomi yang sangat luas, perimbangan keuangan yang lebih adil, proforsional dan transfaran antar setiap lembaga pemerintahan baik untuk tingkat kabupaten kota maupun provinsi. Sejalan dengan hal tersebut maka pemerintah daerah diberi hak otonomi untuk menentukan Anggaran Pendapatan dan Belanja Daerah (APBD) sendiri sesuai dengan kebutuhan dan potensi daerah. Anggaran Pendapatan dan Belanja Daerah yang dituangkan dalam bentuk kebijaksanaan keuangan pemerintah daerah merupakan salah satu komponen pemicu tumbuhnya prekonomian suatu daerah.

Untuk penyusunan APBD memerlukan perhatian terutama dalam pendistribusian anggaran penerimaan pada sector-sektor yang dapat memacu pertumbuhan ekonomi secara berkesinambungan sebagaimana yang telah digariskan dalam pola dasar pembangunan daerah, Rencana pembangunan jangka menengah daerah (RPJMD) priode lima tahun. Sejalan dengan itu untuk melihat keberpihakan pola penyusunan anggaran Pendapatan dan Belanja Daerah yang secara eksplisit dapat dilihat melalui alokasi dana pembangunan daerah menjadai penting untuk dicermati secara lebih mendalam. Mengapa hal ini menjadi sangat penting, karena melalui alokasi dana pembangunan yang dituangkan dalam APBD tersebut akan mencerminkan sistim politik yang dianut oleh pemerintah daerah dalam mengeksekusi program-program yang tertuang dalam APBD-nya. Lebih lanjut análisis alokasi APBD ini akan dapat dilihat melalui alokasi dana APBD ke dalam dana rutin. Alokasi dana rutin secara konseptual digunakan untuk mendukung pelaksanaan eksekusi dana pembangunan.

$$
\text { Distribusi anggaran belanja }
$$

pembangunan melalui berbagai sector kegiatan secara proporsional dapat merupakan kebijakan yang ditempuh oleh pemerintah daerah dalam mendorong sectorsektor strategis guna meningkatkan pertumbuhan ekonomi yang selama ini masih didominasi oleh sector pertanian semata. Secara operasional semestinya alokasi danadana pembangunan memungkinkan untuk dapat mendorong sector ekonomi produktif sehingga secara multiplier dapat meningkatkan pendapaan daerah yang sekaligus meningkatkan pertumbuhan ekonomi daerah melalui peningkatan PDRB. Salah satu strategi yang dapat dilakukan disamping mendorong sector ekonomi produktif juga dapat memelui sector ekonomi dan sosial yang dapat mendatangkan sumber penerimaan baru untuk meningkatkan penerimaan daerah.

Semua kegiatan di atas dapat dilakukan melalui realokasi sistem pengalokasin anggaran pembangunan, dimana paradigma penggunaan anggaran yang selama ini lebih banyak berbasis program atau proyek yang berbasis sosial dapat dialihkan ke program atau proyek yang berbasis ekonomi (value added). Untuk ituk sangat diperlukan análisis mengenai pengalokasian anggaran pembangunan, sehingga pencapaian sasaran pembangunan dapat lebih efisien dan efektif yang pada akhirnya dapat meningkat kesejahtraan masyarakat sebagai penerima manfaat dari pembangunan. 
Melalui otonomi daerah yang telah dituangkan dalam peraturan perundangundangan telah menimbulkan dampak yang cukup luas terhadap kewenangan pemerintah daerah termasuk perimbangan keuangan pusat dan daerah. Secara nyata ketentuanketentuan di atas telah membawa daerah menjadi otonomi yang sangat luas, perimbangan keuangan yang lebih adil, proforsional dan transfaran antar setiap lembaga pemerintahan baik untuk tingkat kabupaten kota maupun provinsi. Kebijakan pemberian otonomi daerah merupakan langkah strategis dalam dua hal. Pertama, otonomi daerah dan desentralisasi merupakan jawaban atas permasalahan lokal bangsa Indonesia berupa ancaman disintegrasi bangsa, kemiskinan, ketidakmerataan pembangunan, rendahnya kualitas hidup masyarakat, dan masalah pembangunan sumber daya manusia. Kedua, otonomi daerah dan desentralisasi merupakan langkah strategis bangsa Indonesia untuk menyongsong era globalisasi ekonomi dengan memperkuat basis perekonomian daerah. (Mardiasmo, 2002:59).

Dari sisi reformasi keuangan sebagai pelaksanaan amanat otonomi, pemerintah telah menetapkan Peraturan Pemerintah Nomor 105 Tahun 2000 tentang Pengelolaan dan Pertanggungjawaban Keuangan Daerah yang mengatur mekanisme dan prosedur pengelolaan keuangan daerah yang transparan dan akuntabel berdasarkan asas kewajaran dan kepatutan. Dengan ditetapkannya Peraturan Pemerintah tersebut semakin membawa perubahan yang mendasar dalam pengelolaan anggaran daerah (APBD). Perubahan mendasar tersebut adalah adanya tuntutan akuntabilitas dan transparansi yang lebih besar dalam pengelolaan anggaran. Sebagaimana menurut Abdul Halim (2002:5) bahwa sebelum reformasi keuangan daerah, pertanggungjawaban atas pengelolaan anggaran daerah lebih ditujukan pada pemerintah yang lebih tinggi. Dengan adanya reformasi, pertanggungjawaban lebih ditujukan kepada rakyat melalui DPRD.

Pergeseran atau reformasi yang mendasar terhadap pengelolaan anggaran daerah memiliki konsekuensi terhadap Anggaran
Pendapatan dan Belanja Daerah (APBD), karena APBD merupakan suatu daftar rincian penerimaan dan belanja daerah yang sekaligus berfungsi sebagai alat atau dasar pengelolaan keuangan daerah dalam setiap tahun anggaran tertentu. Dimana semua penerimaan daerah dan pengeluaran daerah dalam rangka desentralisasi dicatat dan dikelola dalam Anggaran Pendapatan dan Belanja Daerah (APBD).

Terkait dengan fungsi dan tugas pemerintah daerah dalam era otonomi daerah akhir-akhir ini maka, tidak dapat dipungkiri lagi bahwa peranan identifikasi potensi dan sumber perolehan keuangan daerah menjadi sesuatu yang amat penting. Ini diharapkan akan mampu memberikan informasi yang lebih akurat mengenai alternatif sumber-sumber penerimaan daerah guna membiayai penyelenggaraan pemerintahan daerah. Secara implisit ketersediaan data mengenai perkembangan sumber-sumber penerimaan dan pengeluaran daerah dapat dijadikan bahan acuan pemerintah daerah dalam membuat perencanaan dan pola kebijakan pemerintah daerah terutama dalam pengelolaan keuangan daerah yang sekaligus dapat berfungsi sebagai bahan evaluasi sampai sejauhmana tingkat kemandirian dan desentralisasi fiskal daerah di era otonomi daerah sekarang ini.Mengingat APBD merupakan salah satu alat atau instrumen untuk meningkatkan pelayanan publik dan kesejahteraan masyarakat, maka dalam pelaksanaan otonomi daerah proses penyusunan dan pelaksanaan APBD harus sejalan dengan kepentingan dan kebutuhan publik atau masyarakat. Dalam kaitan dengan ini, APBD harus benar-benar dapat mencerminkan kebutuhan masyarakat dengan memperhatikan potensi dan keanekaragaman daerah.

\section{Perumusan Masalah}

1. Bagaimana dampak pengalokasian dana anggaran pembangunan dan anggaran rutin terhadap laju percepatan pertumbuhan ekonomi Kabupaten Lombok Tengah terhitung sejak Tahun 2012-2016.

2. Berapa besar kontribusi danaanggaran pembangunan dan anggaran rutin dalam mendorong laju percepatan pertumbuhan 
ekonomi Kabupaten Lombok Tengah terhitung sejak Tahun 2012-2016.

\section{Tujuan Penelitian}

1. Menganalisis bagaimana dampak pengalokasian dana pembangunan dan dana rutin terhadap laju percepatan pertumbuhan ekonomi Kabupaten Lombok Tengah terhitung sejak Tahun 2012-2016.

2. Menganalisis kontribusi danaanggaran pembangunan dan anggaran rutin terhadap laju percepatan daya dorong pertumbuhan ekonomi Kabupaten Lombok Tengah terhitung sejak Tahun 2012-2016.

\section{Hal-hal yang Akan Dianalisis}

Adapun variabel-variabel yang akan dianalisis dalam penelitian ini meliputi beberapa hal antara lain : Pendapatan Daerah, Pendapatan Asli Daerah, Retrebusi daerah, Pendapatan lain Yang Syah, Belanja Aparatur, Belanja Pelayanan Publik dan Belanja Bagi Hasil

\section{TINJAUAN PUSTAKA}

\section{Hasil Penelitian Terdahulu}

Dalam penelitian yang dilakukan oleh Hasbullah (2006 : 9) yang berjudul Analisis Kemampuan Keuangan Daerah Kota Mataram. Adapun variabel-variabel yang diamati dalam penelitian tersebut meliputi : Pendapatan Daerah, Belanja Daerah, Total Pendapatan Daerah (TPD), Bagi Hasil Pendapatan Bukan Pajak (BHPBP), APBD dan PDRB. Dari hasil kajiannya disimpulkan bahwa proporsi PAD terhadap Total Pendapatan Daerah (TPD) sebesar 7,87 persen, proporsi PAD ditambah BHPBP terhadap TPD sebesar 20,68 persen, rasio PAD terhadap belanja aparatur sebesar 14,16 persen, rasio PAD ditambah BHPBP terhadap belanja aparatur sebesar 37,19 persen. Akan tetapi jika diamati perkembangannya dari tahun ke tahun nampak bahwa proporsi PAD ini semakin menurun. Kondisi ini menunjukkan bahwa ketergantungan pemerintah daerah terhadap pemerintah pusat semakin besar. Ketergantungan yang semakin besar ini antara lain disebabkan oleh kondisi umum yang terjadi di semua kabupaten/kota yang diakibatkan oleh perubahan struktur anggaran seperti : gaji guru SD yang masuk dalam APBD, kenaikan gaji Pegawai Negeri Sipil (PNS). Keadaan ini akan mengakibatkan bertambahnya total APBD yang sumber penerimaannya berasal dari dana sumbangan pemerintah pusat.

Dalam penelitiannya yang lain Hasbullah (2006 : 6) yang berjudul Analisis Rasio Keuangan Pada Anggaran Pendapatan dan Belanja Daerah Kabupaten Lombok Barat. Dimana variabel-variabel yang diamati dalam penelitian tersebut meliputi : Pendapatan Daerah, Belanja Aparatur Daerah, Belanja Pelayanan Publik, Biaya Pungutan PAD, Target Penerimaan PAD dan APBD. Dikatakan bahwa rasio kemandirian menggambarkan ketergantungan pemerintah daerah terhadap sumber dana dari luar (ekstern). Semakin tinggi rasio kemandirian mengandung arti bahwa tingkat ketergantungan pemerintah daerah terhadap bantuan pihak luar/ekstern (terutama pemerintah pusat/provinsi) semakin rendah, dan demikian pula sebaliknya. Rasio kemandirian juga menggambarkan tingkat partisipasi masyarakat dalam pembangunan daerah. Semakin tinggi rasio kemandirian, semakin tinggi pula partispasi masyarakat dalam membayar pajak dan retribusi daerah yang merupakan komponen utama pendapatan asli daerah (PAD). Semakin tinggi masyarakat membayar pajak dan retrebusi daerah akan dapat menggambarkan tingkat kesejahtraan masyarakat yang semakin tinggi pula. Berdasarkan hasil kajiannya sejak Tahun Anggaran 2002 - 2005 disimpulkan bahwa besarnya rasio kemandirian keuangan kabupaten Lombok Barat sebesar 8,70 persen, 6,65 persen, 8,34 persen dan 8,09 persen. Ini berarti kemandirian daerah Kabupaten Lombok Barat dalam mencukupi kebutuhan pembiayaan untuk melakukan tugas pemerintahan, pembangunan dan pelayanan masyarakat relatif masih rendah bahkan cendrung menurun.

\section{Landasan Teori}

\section{Kinerja Keuangan Daerah}

Menurut Nizarwan dalam Halim (2004 : 70) dalam bukunya yang berjudul Bunga Rampai Manajemen Keuangan Daerah mengatakan Kebijakan umum pengelolaan keuangan daerah disesuaikan dengan situasi dan kondisi serta potensi daerah dengan berpedoman pada Undang-undang Nomor : 32 Tahun 2004 dan Undang-undang Nomor 
: 33 tahun 2004. Kesimpulannya adalah Kebijakan pengelolaan keuangan daerah dalam mengalokasikan belanja aparatur dan belanja pelayanan publik senantiasa berpegang pada prinsip anggaran berimbang dan dinamis serta efisien dan efektif dalam meningkatkan produktivitas. Menurut Mardiasmo (2004) dalam bukunya yang berjudul Otonomi dan Manajemen Keuangan Daerah mengatakan Anggaran merupakan pernyataan mengenai estimasi kinerja yang hendak dicapai selama priode waktu tertentu yang dinyatakan dalamukuran finansial dan berisi rencana kegiatan yang direpresentasikan dalam bentuk rencana perolehan pendapatan dan belanja dalam satuan moneter.

Menurut Indra Bastian (2001 : 6) dalam bukunya yang berjudul Manual Akuntansi Keuangan Pemerintah Daerah mengatakan bahwa penyusunan APBD adalah suatu hal yang sangat penting dalam rangka penyelenggaraan fungsi daerah otonom yang bertujuan untuk : menentukan jumlah pajak yang akan dibebankan kepada masyarakat, suatu sarana untuk mewujudkan otonomi yang nyata dan bertanggung jawab, memberi isi dan arti dari pemerintah pusat ke pemerintah daerah, sarana untuk pengawasan dan pemberian kuasa kepala daerah untuk penyelenggaraan keuangan daerah.

\section{Pengelolaan Keuangan Daerah}

Dalam Peraturan Pemerintah Nomor 58 Tahun 2005 pengganti Peraturan Pemerintah Nomor 105 Tahun 2000 memberikan definisi Pengelolaan Keuangan Daerah adalah keseluruhan kegiatan yang meliputi perencanaan, pelaksanaan, penatausahaan, pelaporan, pertanggungjawaban, dan pengawasan keuangan daerah sedangkan Undangundang Nomor 17 Tahun 2003 tentang Keuangan Negara bahwa pendapatan daerah dan belanja daerah yang merupakan bagian dari keuangan negara harus dikelola secara tertib, taat pada peraturan perundang-undangan, efisien, ekonomis, efektif, transparan, dan bertanggungjawab dengan memperhatikan rasa keadilan dan kepatuhan.
Menurut Jaya dalam Munir, Djuanda, Tangkilisan (2004: 6) Keuangan Daerah adalah seluruh tatanan, perangkat kelembagaan dan kebijaksanaan anggaran daerah yang meliputi pendapatan dan belanja daerah, sedangkan menurut Peraturan Pemerintah Nomor 105 Tahun 2000 menjelaskan Keuangan Daerah adalah semua hak dan kewajiban daerah dalam rangka penyelenggaraan pemerintahan daerah yang dapat dinilai dengan uang termasuk didalamnya segala bentuk kekayaan yang berhubungan dengan hak dan kewajiban daerah tersebut, dalam kerangka Anggaran Pendapatan dan Belanja Daerah (APBD). Menurut Bastian (2001:8) adanya hubungan yang erat antara Keuangan Negara dan Keuangan Daerah yang merupakan dasar pengelolaan keuangan daerah. Sehingga baik dalam penyusunan APBD dan pelaporan keuangan daerah maupun pelaksanaannya, menceminkan pelaksanaan otonomi daerah yang nyata dan bertanggungjawab yang mencakup hal - hal sebagai berikut (1) Harus serasi dengan pembinaan politik dan kesatuan bangsa; (2) Harus dapat menjamin hubungan yang serasi antara pemerintah pusat dan pemerintah daerah atas dasar keutuhan negara kesatuan; (3) Harus dapat menjamin perkembangan dan pembangunan daerah termasuk prinsip - prinsip pembagian sumber - sumber keuangan yang adil; (4) Mampu memberdayakan dan meningkatkan kemampua perekonomian daerah; (5) Dapat menciptakan sistem pembiayaan daerah yang adil, proporsional, rasional, transparan, partisipatif, bertanggungjawab (akuntabel) dan pasti; dan (6) Semakin mempertegas sistem pertanggungjawaban keuangan oleh Pemerintah Daerah.

Menurut Devas et al dikutip dalam Munir, Djuanda, Tangkilisan (2004: 7) pengelolaan keuangan daerah berarti mengurus dan mengatur keuangan daerah itu sendiri berdasarkan pada prinsip-prinsip : (1) tanggung jawab, (2) mampu memenuhi kewajiban keuangan, (3) kejujuran, (4) hasil guna dan daya guna, dan (5) pengendalian. Melalui misi utama dan tujuan utama pengelolaan keuangan daerah di atas, terlihat bahwa pemerintah daerah harus mempertanggung jawabkan tugas keuangannya kepada lembaga atau orang 
yang berkepentingan yang sah, yang meliputi DPRD dan masyarakat. Selain itu efektivitas dan efisiensi dalam pengelolaan keuangan daerah juga harus dilaksanakan. Hal ini berarti dalam pengelolaan keuangan daerah harus dilaksanakan sedemikian rupa sehingga program dan kegiatan yang telah direncanakan dapat dilaksanakan untuk mencapai tujuan pemerintah daerah dengan biaya yang serendah-rendahnya dan dalam waktu yang secepat-cepatnya. Secara garis besar, manajemen keuangan daerah dapat dibagi menjadi dua bagian, yaitu manajemen penerimaan daerah dan manajemen pengeluaran daerah. Kedua komponen tersebut akan sangat menentukan kedudukan suatu pemerintah daerah dalam rangka melaksanakan otonomi daerah (Mardiasmo, 2002).

\section{Anggaran Pendapatan dan Belanja Daerah (APBD)}

Sesuai Peraturan Pemerintah Nomor 105 Tahun 2000 tentang Pengelolaan dan pertanggungjawaban Keuangan Daerah, APBD adalah suatu rencana keuangan tahunan daerah yang ditetapkan berdasarkan Peraturan Daerah tentang APBD. Dengan demikian, pemungutan semua penerimaan daerah dalam rangka pelaksanaan desentralisasi bertujuan untuk memenuhi target yang ditetapkan dalam APBD. Semua pengeluaran daerah dan ikatan yang membebani daerah dalam rangka pelaksanaan desentralisasi dilakukan sesuai jumlah dan sasaran yang ditetapkan dalam APBD, sehingga APBD menjadi dasar bagi kegiatan pengendalian, pemeriksaan dan pengawasan keuangan daerah. APBD merupakan dasar pengelolaan keuangan daerah dalam tahun anggaran tertentu.

Menurut UU Nomor 32 Tahun 2004 tentang Pemerintahan Daerah sumber penerimaan daerah terdiri dari (1) Pendapatan Asli Daerah (PAD), (2) Dana Perimbangan dan (3) Lain-lain pendapatan daerah yang syah.Sedangkan menurut UU Nomor 33 Tahun 2004 tentang Perimbangan Keuangan Antara Pemerintah Pusat dan Pemerintah Daerah dalam pasal 5 ayat (1) menyatakan bahwa penerimaan daerah dalam pelaksanaan desentralisasi terdiri atas pendapatan daerah dan pembiayaan.
Selanjutnya ayat 2 menjelaskan bahwa pendapatan daerah sebagaimana dimaksud pada ayat 1 bersumber dari : (1) Pendapatan Asli Daerah (PAD), (2) Dana

Perimbangan dan (3) Lain-lain pendapatan. Menurut Surat Edaran Menteri Dalam Negeri RI Nomor 903/2477/SJ tanggal 5 Desember 2001 perihal Pedoman Umum Penyusunan dan Pelaksanaan APBD Tahun Anggaran 2002, bahwa penyusunan APBD harus mengacu pada norma dan prinsip anggaran sebagai berikut:

1. Transparansi dan Akuntabilitas Anggaran Merupakan persyaratan utama untuk mewujudkan pemerintahan yang baik, bersih dan bertanggungjawab. Sebagai instrument evaluasi pencapaian kinerja dan tanggungjawab Pemerintah Daerah mensejahterakan masyarakat, maka APBD harus dapat menyajikan informasi yang jelas tentang tujuan, sasaran, hasil dan manfaat yang diperoleh masyarakat dari suatu kegiatan atau proyek yang dianggarkan yang meliputi :

\section{a. Disiplin Anggaran}

APBD harus disusun berorientasi pada kebutuhan masyarakat tanpa harus meninggalkan keseimbangan antara pembiayaan penyelenggaraan pemerintahan, pembangunan dan pelayanan masyarakat.Oleh karena itu penyusunan anggaran hendaknya dilakukan berlandaskan azas efisiensi, tepat guna, tepat waktu pelaksanaan dan penggunaannya dapat dipertanggungjawabkan.

\section{b. Keadilan Anggaran}

Pendapatan Daerah pada hakekatnya diperoleh melalui mekanisme pajak dan retribusi atau beban lainnya yang dipikul oleh segenap lapisan masyarakat.Untuk itu, Pemerintah Daerah wajib mengalokasikan pengunaannya secara adil dan merata agar dapat dinikmati oleh seluruh kelompok masyarakat tanpa 
diskriminasi dalam pemberian pelayanan.

Menurut Mardiasmo anggaranmerupakan pernyataan mengenai estimasi kinerja yang hendak dicapai selama periode waktu tertentu yang dinyatakan dalam ukuran finansial dan berisi rencana kegiatan yang direpresentasikan dalam bentuk rencana perolehan pendapatan dan belanja dalam satuan moneter.Anggaran sektor publik merupakan instrumen akuntabilitas atas pengelolaan dana publik dan pelaksanaan program - program yang dibiayai dengan uang publik. Penganggaran sektor publik terkait dengan proses penentuan jumlah alokasi dana untuk tiap tiap program dan aktifitas dalam satuan moneter

\section{Kerangka Konseptual}

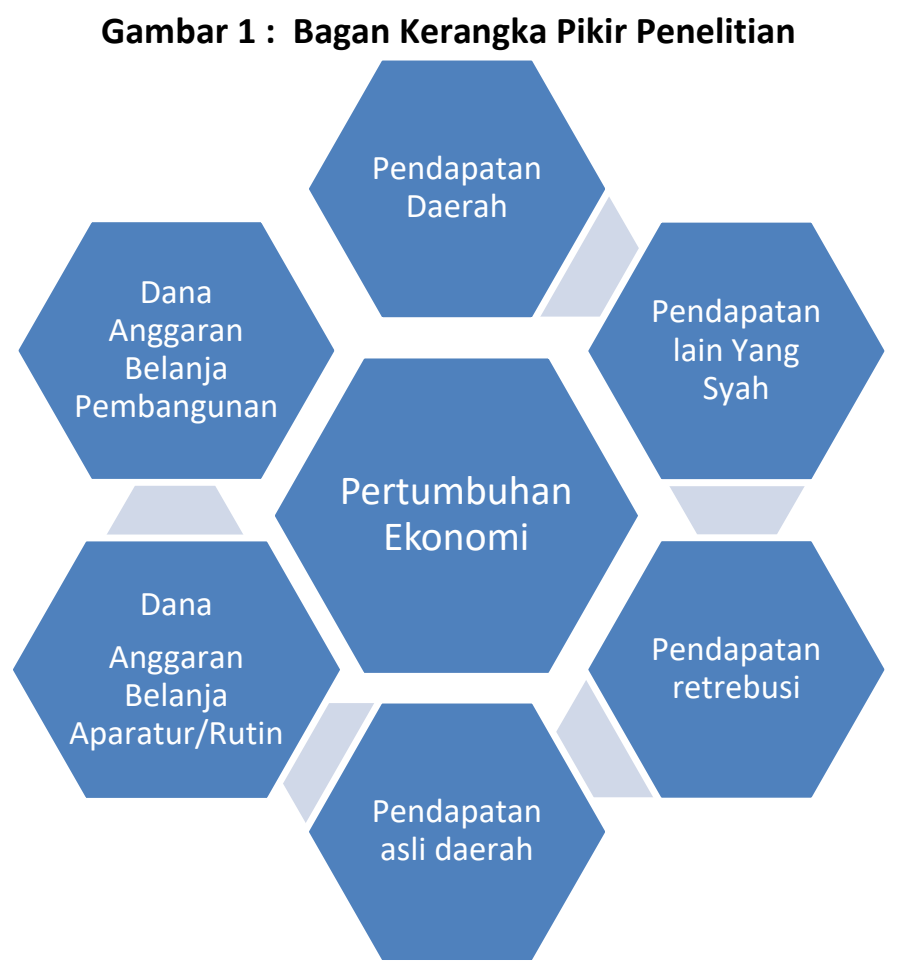

\section{METODE PENELITIAN}

\section{Jenis Penelitian}

Penelitian ini termasuk penelitian deskriptif, yang dilakukan untuk mengetahui nilai variabel mandiri, baik satu variabel atau lebih (independent) tanpa membuat perbandingan atau menghubungkan dengan variabel yang lain (Sugiyono, 1999:11). Selanjutnya menurut Kuncoro (2003:8) Penelitian deskriptif meliputi pengumpulan data untuk diuji hipotesis atau menjawab pertanyaan mengenai status terakhir dari subjek penelitian. Penelitian deskriptif berupaya untuk memperoleh deskripsi yang lengkap dan akurat dari suatu situasi.

\section{Lokasi Penelitian}

Penelitian ini dilaksanakan di Kabupaten Lombok Tengah Provinsi Nusa Tenggara Barat, dipilinnya Kabupaten Lombok Tengah secara purposive sampling dengan dasar pertimbangan bahwa Kabupaten Lombok Tengah merupakan salah satu daerah Kabupaten di Provinsi Nusa Tenggara Barat yang paling banyak dan terpadat jumlah penduduknya jika dibandingkan dengan kabupaten lain di Provinsi Nusa Tenggara Barat. Diharapkan dengan terpilihnya Kabupaten Lombok Tengah sebagai lokasi penelitian akan memberikan berbagai kemudahan dari berbagai akses seperti data dan informasi lainnya. 


\section{Teknik dan Alat Pengumpulan Data}

Data yang berkaitan dengan analisis dana perimbangan dilakukan dengan cara :

1. Studi kepustakaan (Library Research), yaitu dengan cara mempelajari buku-buku, karangan ilmiah, jurnal ilmiah serta dokumen-dokumen lain yang berkaitan dengan analisis pertumbuhan ekonomi sesuai dengan judul penelitian.

2. Penelitian lapangan (Field Research), yaitu melakukan pengamatan secara langsung di lapangan terutama pada Biro Keuangan Sekretariat Daerah Kabupaten Lombok Tengah Provinsi NTB sehubungan dengan data-data dan informasi terkait dengan variabel-variabel penelitian di atas.

\section{Jenis dan Sumber Data}

Penelitian ini menggunakan data skunder yaitu data yang sudah dikumpulkan langsung dari Biro sekretariat Daerah Kabupaten Lombok Tengah sesuai data yang diperlukan dalam penelitian. Adapun data yang dimaksudkan terdiri dari : data APBD, Perubahan APBD, laporan perhitungan APBD, realisasi penerimaan daerah, realisasi belanja daerah, Nota Perhitungan APBD, Arus Kas dan Buku Perhitungan APBD, data PDRB, data demografis, perkembangan APBD, penerimaan dan belanja daerah, dan mekanisme penganggaran serta data-data Kabupaten Lombok Tengah lainnya yang mendukung judul penelitian Kabupaten Lombok Tengah Provinsi NTB Tahun Anggaran 2012-2016.

\section{Identifikasi dan Klasifikasi Variabel}

Dalam penelitian ini variabel yang diidentifikasi adalah sebagai berikut:

1. Pendapatan Daerah

2. Pendapatan Asli Daerah

3. Dana Anggaran Pembangunan

4. Dana anggaran rutin

5. Pendapatan lain Yang Syah

6. Produk Domestik Regional Brutto

\section{Definisi Operasional Variabel}

Untuk menghindari penafsiran yang berbeda terhadap beberapa variabel yang digunakan dalam penelitian ini maka diberikan batasanbatasan sebagai berikut

1. Pendapatan Daerah (PD) adalah semua penerimaan kas daerah dalam periode tahun anggaran tertentu yang menjadi hak daerah, tidak termasuk didalamnya unsur penerimaan UKP dalam kurun waktu tertentu (satu tahun)

2. Dana Pembangunan adalah dana yang digunakan untuk mendanai penyelenggaraan pembangunan daerah baik yang berasal dari pemerintah pusat yang terdiri dari dana alokasi umum (DAU) dan dana alokasi khusus (DAK) maupun yang .berasal dari pendapatan daerah.

3. Pendapatan lain Yang Syah adalah pendapatan daerah yang berasal dari berbagai sumber diantaranya bisa berasal dari deviden dalam penyertaan modal daerah, hibah baik yang berasal dari pemerintah pusat maupun dari pihak luar.

4. Belanja Aparatur adalah semua pengeluaran kas daerah yang dipergunakan untuk mendanai administrasi penyelenggaraan pemerintahan daerah seperti : gaji Pegawai Negeri Sipil (PNS), Vakasi, lembur, pengadaan sarana dan parasarana birokrasi serta fasilitas lainnya termasuk pemeliharaan fasilitas inventaris yang sekaligus akan menjadi beban daerah dalam kurun waktu tertentu (satu tahun).

5. Belanja Pelayanan Publik adalah semua pengeluaran kas daerah yang dipergunakan untuk mendanai seluruh aktivitas pelayan publik seperti : pembangunan sarana pendidikan, sarana kesehatan, sarana perhubungan dan fasilitas umum lainnya yang dibutuhkan masyarakat sekaligus akan menjadi beban daerah dalam kurun waktu tertentu (satu tahun).

6. Belanja Bagi Hasil adalah dana yang dialokasikan dari anggaran pendapatan belanja daerah (APBD) untuk keperluan penyertaan modal daerah dalam perusahaan daerah.

7. Belanja Daerah adalah adalah semua pengeluaran kas daerah dalam periode tahun anggaran tertentu yang menjadi beban daerah, terdiri dari belanja aparatur dan belanja pelayanan publik. 
8. Produk Domestik Regional Brutto (PDRB) adalah seluruh nilai produk barang dan jasa yang diproduksi di wilayah Kabupaten Lombok Tengah tanpa memperhatikan apakah faktor produksinya berasal dari/atau dimiliki oleh penduduk Kabupaten Lombok Tengah selama jangka waktu tertentu (satu tahun).

\section{ANALISIS DATA}

\section{Rasio Kemandirian dan Kinerja Keuangan Daerah}

Kemandirian dan kinerja keuangan daerah menunjukkan kemampuan daerah dalam membiayai dirinya sendiri dalam pelaksanaan kegiatan administrasi pemerintahan, pembangunan dan pelayanan kepada masyarakat (publik) yang telah membayar pajak, retrebusi, hasil pengelolan kekayaan daerah serta lain-lain PAD yang syah. Kemandirian dan kinerja keuangan daerah dimaksud dapat ditunjukkan melalui ratio beberapa indikator seperti : Rasio pendapatan daerah, Rasio PAD Terhadap Pendapatan Daerah, Rasio Dana Pembangun Terhadap Pertumbuhan ekonomi, Rasio dana Rutin terhadap pertumbuhan ekonomi, Rasio Pendapatan lain Yang Syah Terhadap Pendapatan Daerah,Rasio Belanja Aparatur Terhadap Pendapatan Daerah, Rasio Belanja Bagi HasilTerhadap Pendapatan Daerah, Rasio Belanja Pelayanan PublikTerhadap Pendapatan Daerah, Rasio Produk Domestik Regional Brutto Terhadap Pendapatan Daerah, kontribusi belanja pembangunan terhadap pertumbuhan ekonomi dankontribusi belanja rutin terhadap pertumbuhan ekonomi daerah.

\section{HASIL DAN PEMBAHASAN}

\section{Perkembangan Kondisi Keuangan Daerah}

Realisasi pendapatan daerah Kabupaten Lombok Tengah tahun 2016 sebesar 2,22 Trilyun Rupiah meningkat sekitar 200 milyar rupiah atau 12,9 persen dibandingkan dengan realisasi di tahun 2015. Dilihat dari komposisinya sebagian besar pendapatan ini bersumber dari berasal dari Dana alokasi Umum (DAU). Pada tahun 2016 DAU yang diterima sebesar 1,16 Trilyun atau sekitar 52,29 persen dari total pendapatan daerah. Sedangkan pendapatan yang berasal dari Pendapatan Asli Daerah (PAD) tidak terlalu besar dilihat daripersentasinya terhadap total pendapatan. Tahun 2016 PAD Kabupaten Lombok Tengah berjumlah 236 milyar atau sekitar 10,62 persen saja. Meskipun demikian jumlah PAD dari tahun ke tahun terus mengalami peningkatan. Jika dilihat dari segi penggunaan atau belanja daerah, total belanja daerah mencapai 2,23 trilyun pada tahun 2016. Lebih besar dibandingkan dengan belanja tahun 2015 yang mencapai 1,66 trilyun. Dari komponen belanja daerah tersebut, belanja pegawai ternyata merupakan komponen yang paling besar. Sebagai ilustrasi jumlah belanja pegawai pada tahun 2016 mencapai 1,09 trilyun atau sekitar 48,89 persen dari total belanja daerah.

Jika dilihat kondisi pendapatan daerah Kabupaten Lombok Tengah tahun 2015 sebesar 1,91 Trilyun rupiah terjadi peningkatan sekitar 218,6 milyar rupiah atau sebesar 12,9 persen jika dibandingkan dengan realisasi pada tahun 2014. Jika dilihat dari segi kompisisnya sebahagian besar pendapatan ini berasal dari Dana Alokasi Umum (DAU). Pada tahun 2015 jumlah DAU yang diterima mencapai 1,08 Trilyun atau sekitar 56,5 persen dari total pendapatan daerah. Sedangkan pendapatan yang bersumber dari Pendapatan Asli Daerah (PAD) tidak terlalu besar dilihat dari segi persentasinya terhadap total pendapatan. Sebagai ilustrasi pada tahun 2015 PAD Kabupaten Lombok Tengah sejumlah 189,27 milyar atau sekitar 9,9 persen dari total pendapatan daerah. Mekipun demikian jumlah PAD Kabupaten Lombok Tengah dari tahun 
ke tahun menunjukkan angka peningkatan.Jika dilihat dari segi penggunaan atau belanja daerah, total belanja daerah mencapai 1,66 trilyun pada tahun 2015 . Lebih besar dibandingkan dengan belanja tahun 2014yang mencapai 1,62 trilyun. Dari komponen belanja daerah tersebut, belanja pegawai ternyata merupakan komponen yang paling besar. Sebagai ilustrasi jumlah belanja pegawai pada tahun 2015 mencapai 1,02 trilyun atau sekitar 61,35 persen dari total belanja daerah.

Selanjutnya secara lebih komprehensif untuk melihat laju pertumbuhan Pendapatan Daerah Kabupaten Lombok Tengah sejak tahun 2012-2016 akan disajikan pada tabel di bawah :

Tabel 1. Pendapatan Daerah Kabupaten Lombok Tengah Tahun 2012-2016

\begin{tabular}{|c|c|c|c|}
\hline Tahun & $\begin{array}{c}\text { Target } \\
\text { Anggaran }\end{array}$ & Realisasi Anggaran & Pertumbuhannya (\%) \\
\hline 2012 & $110.789 .153 .137,00$ & $77.013 .503 .318,00$ & 69,51 \\
\hline 2013 & $114.429 .121 .133,82$ & $123.145 .732 .572,78$ & 170,62 \\
\hline 2014 & $131.173 .268 .474,00$ & 140.497 .134 .570 .16 & 107,11 \\
\hline 2015 & $154.863 .589 .503,00$ & $156.931 .857 .545,88$ & 101,34 \\
\hline 2016 & $157.674 .326 .963,00$ & $166.443 .247 .023,43$ & 105,56 \\
\hline J u m I a h & $\mathbf{6 6 8 . 9 2 9 . 4 5 9 . 2 1 0 , 0 0}$ & $\mathbf{6 6 4 . 0 3 1 . 4 7 5 . 0 2 8 , 0 0}$ & $\mathbf{5 5 4 , 1 4}$ \\
\hline Rata-rata & $\mathbf{1 3 3 . 7 8 5 . 8 9 1 . 8 4 2 , 0 0}$ & $\mathbf{1 3 2 . 8 0 6 . 2 9 5 . 0 0 5 , 0 0}$ & $\mathbf{1 1 0 , 8 2}$ \\
\hline
\end{tabular}

Sumber : Kabupaten Lombok Tengahdalam Angka 2012-2016, diolah

Berdasarkan data tabel di atas dapat dijelaskan bahwa angka pertumbuhan pendapatan daerah dilihat dari sisi target dengan realisasi anggaran tahun 2012 sebesar 69,51 persen, tahun 2013 sebesar 170,62persen, tahun 2014 sebesar 107,11 persen, tahun 2015 sebesar 101,34 persen dan tahun 2016 sebesar 105,56 persen. Angka pertumbuhan tertinggi terjadi pada tahun 20143 yaitu sebesar 170,62persen. Angka pertumbuhan rata-rata selama 5 (lima) tahun terhitung sejak tahun 2012-2016 mencapai 110,82 persen

\section{Perkembangan Pendapatan Asli Daerah} (PAD)

Penjelasan berikutnya akan disajikan bagaimana pertumbuhan dan perkembangan pendapatan asli daerah Kabupaten Lombok Tengah selama 5 (lima) tahun terakhir akan disajikan pada tabel di bawah :

Tabel 2. Dana Retrebusi DaerahKabupaten Lombok Tengah Tahun

2012-2016 (jutaan rupiah)

\begin{tabular}{|c|c|c|c|}
\hline Tahun & Target Anggaran & Realisasi Anggaran & Pertumbuhannya (\%) \\
\hline 2012 & 27.420 .126 .285 & 19.454 .046 .307 & 70,00 \\
\hline 2013 & 26.677 .585 .320 & 19.562 .362 .475 & 73,33 \\
\hline 2014 & 39.474 .382 .856 & 27.805 .602 .322 & 70,44 \\
\hline 2015 & 30.972 .090 .918 & 18.694 .048 .163 & 60,36 \\
\hline 2016 & 24.499 .322 .744 & 14.459 .604 .276 & 59,02 \\
\hline J u m I a h & $\mathbf{1 . 4 9 0 . 4 3 5 . 0 8 1 , 2 3}$ & $\mathbf{9 9 9 . 7 5 6 . 6 3 5 , 4 3}$ & $\mathbf{2 6 3 , 8 5}$ \\
\hline Rata-rata & $\mathbf{2 9 8 . 0 8 7 . 0 1 6 , 2 4}$ & $\mathbf{1 9 9 . 9 5 1 . 3 2 7 , 0 8}$ & $\mathbf{5 2 , 7 7}$ \\
\hline
\end{tabular}

Sumber : Kabupaten Lombok Tengahdalam Angka 2012-2016, diolah

Berdasarkan data tabel di atas dapat dijelaskan bahwa angka pertumbuhan Dana Retrebusi daerah dapat dilihat dari segi target dengan realisasi anggaran terhitung sejak tahun 2012 pertumbuhannya sebesar 70,00 persen, tahun 2013 menjadi sebesar 73,33 persen, tahun 2014 menjadi sebesar 70,44 persen, tahun 2015 menurun menjadi sebesar 
60,36 persen dan tahun 2016 turun menjadi sebesar 59,02 persen. Angka pertumbuhan tertinggi terjadi pada tahun 2013 yaitu sebesar 73,33 persen. Angka pertumbuhan rata-rata selama 5 (lima) tahun terhitung sejak tahun 2012-2016 mencapai 52,77 persen.

\section{Perkembangan Dana Retrebusi Daerah}

Selanjutnya untuk melihat bagaimana realisasi dan pertumbuhan Dana Retrebusi selama 5 (lima) tahun sejak tahun 20122016 akan disajikan pada tabel di bawah ini

Tabel 3. Dana Retrebusi DaerahKabupaten Lombok Tengah Tahun 2012-2016 (jutaan rupiah)

\begin{tabular}{|c|c|c|c|}
\hline Tahun & Target Anggaran & Realisasi Anggaran & Pertumbuhannya (\%) \\
\hline 2012 & 27.420 .126 .285 & 19.454 .046 .307 & 70,00 \\
\hline 2013 & 26.677 .585 .320 & 19.562 .362 .475 & 73,33 \\
\hline 2014 & 39.474 .382 .856 & 27.805 .602 .322 & 70,44 \\
\hline 2015 & 30.972 .090 .918 & 18.694 .048 .163 & 60,36 \\
\hline 2016 & 24.499 .322 .744 & 14.459 .604 .276 & 59,02 \\
\hline J u m I a h & $\mathbf{1 . 4 9 0 . 4 3 5 . 0 8 1 , 2 3}$ & $\mathbf{9 9 9 . 7 5 6 . 6 3 5 , 4 3}$ & $\mathbf{2 6 3 , 8 5}$ \\
\hline Rata-rata & $\mathbf{2 9 8 . 0 8 7 . 0 1 6 , 2 4}$ & $\mathbf{1 9 9 . 9 5 1 . 3 2 7 , 0 8}$ & $\mathbf{5 2 , 7 7}$ \\
\hline
\end{tabular}

Sumber : Kabupaten Lombok Tengahdalam Angka 2012-2016, diolah.

Berdasarkan data tabel di atas dapat dijelaskan bahwa angka pertumbuhan Dana Retrebusi daerah dapat dilihat dari segi target dengan realisasi anggaran terhitung sejak tahun 2012 pertumbuhannya sebesar 70,00 persen, tahun 2013 menjadi sebesar 73,33 persen, tahun 2014 menjadi sebesar 70,44 persen, tahun 2015 menurun menjadi sebesar 60,36 persen dan tahun 2016 turun menjadi sebesar 59,02 persen. Angka pertumbuhan tertinggi terjadi pada tahun 2013 yaitu sebesar 73,33 persen. Angka pertumbuhan rata-rata selama 5 (lima) tahun terhitung sejak tahun 2012-2016 mencapai 52,77 persen.

\section{PerkembanganPenerimaan Hasil Perusda dan Pengelolaan Kekayaan Daerah Yang Dipisahkan.}

Selanjutnya untuk melihat bagaimana realisasi dan pertumbuhan Penerimaan Hasil Perusda dan Pengelolaan Kekayaan Daerah Yang Dipisahkan selama 5 (lima) tahun sejak tahun 2012-2016 akan disajikan pada tabel di bawah ini :

Tabel 4. Perkembangan Penerimaan Hasil Perusda dan Pengelolaan Kekayaan Daerah Yang Dipisahkan Kabupaten Lombok Tengah Tahun 2012-2016 (Rupiah)

\begin{tabular}{|c|c|c|c|}
\hline Tahun & $\begin{array}{c}\text { Target } \\
\text { Anggaran }\end{array}$ & $\begin{array}{c}\text { Realisasi } \\
\text { Anggaran }\end{array}$ & Pertumbuhannya (\%) \\
\hline 2012 & 3.688 .840 .000 & 4.065 .980 .656 & 116,17 \\
\hline 2013 & 5.743 .707 .383 & 5.610 .383 .433 & 97,68 \\
\hline 2014 & 6.155 .723 .764 & 7.202 .392 .078 & 117,00 \\
\hline 2015 & 8.810 .808 .703 & 8.822 .526 .523 & 100,13 \\
\hline 2016 & 3.357 .884 .508 & 10.962 .220 .871 & 326,46 \\
\hline J u m I a h & $\mathbf{2 7 . 7 5 6 . 9 6 4 . 3 5 8}$ & $\mathbf{3 6 . 6 6 3 . 5 0 3 . 5 6 1}$ & $\mathbf{7 5 7 , 4 4}$ \\
\hline Rata-rata & $\mathbf{5 . 5 5 1 . 3 9 2 . 8 7 1 , 6}$ & $\mathbf{7 . 3 3 2 . 7 0 0 . 7 1 2}$ & $\mathbf{1 5 1 , 4 8}$ \\
\hline
\end{tabular}

Sumber : Kabupaten Lombok Tengah dalam Angka 2012-2016, diolah.

Berdasarkan data tabel di atas dapat dijelaskan bahwa angka pertumbuhan Penerimaan Hasil Perusda dan Pengelolaan Kekayaan Daerah Yang Dipisahkan dilihat dari segi target penerimaan dengan realisasi anggaran terhitung sejak tahun 2012 pertumbuhannya sebesar 116,17 persen,

tahun 2013 menjadi sebesar 97,68 persen, tahun 2014 naik menjadi sebesar 117,00 persen, tahun 2015 turun menjadi sebesar 
100,13 persen dan tahun 2016 meningkat menjadi sebesar 326,46 persen. Angka pertumbuhan tertinggi terjadi pada tahun 2016 yaitu sebesar 326,46 persen. Angka pertumbuhan rata-rata selama 5 (lima) tahun terhitung sejak tahun 2012-2016 mencapai 151,48 persen.

\section{Perkembangan Belanja Bagi Hasil}

Selanjutnya untuk melihat bagaimana realisasi dan pertumbuhan Belanja Bagi Hasil selama 5 (lima) tahun sejak tahun 2012-2016 akan disajikan pada tabel di bawah ini

Tabel 5. Belanja Bagi HasilKabupaten Lombok Tengah Tahun 2012-2016 (jutaan rupiah)

\begin{tabular}{|c|c|c|c|}
\hline Tahun & $\begin{array}{c}\text { Target } \\
\text { Anggaran }\end{array}$ & $\begin{array}{c}\text { Realisasi } \\
\text { Anggaran }\end{array}$ & Pertumbuhannya (\%) \\
\hline 2012 & $149.475,00$ & $158.018,61$ & 6,04 \\
\hline 2013 & $195.012,78$ & $210.700,00$ & 33,33 \\
\hline 2014 & $139.538,90$ & $227.093,61$ & $-75,83$ \\
\hline 2015 & $204.500,22$ & $226.997,92$ & $-0,40$ \\
\hline 2016 & $405.279,01$ & $421.798,35$ & 85,81 \\
\hline J u m I a h & $\mathbf{8 0 8 0 . 8 0 5 , 9 1}$ & $\mathbf{6 9 8 . 9 8 2 , 5 2}$ & $\mathbf{4 8 , 9 5}$ \\
\hline Rata-rata & $\mathbf{1 6 1 . 7 6 1 , 1 8}$ & $\mathbf{1 3 9 . 7 9 6 , 5 0}$ & $\mathbf{9 , 7 9}$ \\
\hline
\end{tabular}

Sumber :Kabupaten Lombok Tengah dalam Angka 2012-2016, diolah.

Berdasarkan data tabel di atas dapat dijelaskan bahwa angka pertumbuhan Belanja Bagi Hasil dilihat dari segi target anggaran dengan realisasi anggaran terhitung sejak tahun 2012 pertumbuhannya sebesar 6,04 persen, tahun 2013 naik menjadi sebesar 33,33 persen, tahun 2014 turun menjadi sebesar $-75,83$ persen, tahun 2015 turun lagi menjadi sebesar $-0,40$ persen dan tahun 2016 meningkat menjadi sebesar 85,81 persen.
Angka pertumbuhan tertinggi terjadi pada tahun 2016 yaitu sebesar 85,81 persen. Angka pertumbuhan rata-rata selama 5 (lima) tahun terhitung sejak tahun 2012-2016 mencapai 9,79 persen.

\section{Perkembangan Belanja Pelayanan Publik}

Selanjutnya untuk melihat bagaimana realisasi dan pertumbuhan Belanja Pelayanan Publik selama 5 (lima) tahun sejak tahun 2012-2016 akan disajikan pada tabel di bawah ini :

Tabel 6. Belanja Pelayanan Publik Kabupaten Lombok Tengah Tahun 2012-2016 (jutaan rupiah)

\begin{tabular}{|c|c|c|c|}
\hline Tahun & $\begin{array}{c}\text { Target } \\
\text { Anggaran }\end{array}$ & $\begin{array}{c}\text { Realisasi } \\
\text { Anggaran }\end{array}$ & Pertumbuhannya (\%) \\
\hline 2012 & 185.779 & 274.134 & 48,11 \\
\hline 2013 & 291.413 & 323.322 & 74,59 \\
\hline 2014 & 381.564 & 446.683 & 38,08 \\
\hline 2015 & 446.683 & 469.315 & 5,16 \\
\hline 2016 & 725.428 & 747.566 & 59,27 \\
\hline J u m I a h & $\mathbf{2 . 1 1 9 . 8 6 7}$ & $\mathbf{2 . 1 7 2 . 0 2 0}$ & $\mathbf{2 2 5 , 2 1}$ \\
\hline Rata-rata & $\mathbf{4 2 3 . 9 7 3}$ & $\mathbf{4 3 4 . 4 0 4}$ & $\mathbf{4 5 , 0 4}$ \\
\hline
\end{tabular}

Sumber : Kabupaten Lombok Tengahdalam Angka 2012-2016, diolah.

Berdasarkan data tabel di atas dapat dijelaskan bahwa angka pertumbuhan Belanja Pelayanan Publik dilihat dari segi target dengan realisasi anggaran terhitung sejak tahun 2012 pertumbuhannya sebesar 48,11 persen, tahun 2013 meningkat menjadi sebesar 74,59 persen, tahun 2014 menjadi sebesar 38,08 persen, tahun 2015 turun menjadi sebesar 5,16 persen dan tahun 2016 meningkat menjadi sebesar 59,27 persen. 
Angka pertumbuhan tertinggi terjadi pada tahun 2013 yaitu sebesar 74,59 persen. Angka pertumbuhan rata-rata selama 5 (lima) tahun terhitung sejak tahun 2012-2016 mencapai 45,04 persen.

\section{Perkembangan Pendapatan Lain Yang Syah}

Selanjutnya untuk melihat bagaimanaangka pertumbuhan Pendapatan Lain Yang Syah selama 5 (lima) tahun sejak tahun 2012-2016 dilihat dari segi target anggaran dengan realisasinya akan disajikan pada tabel di bawah ini :

Tabel 7. Pendapatan Lain Yang Syah Kabupaten Lombok Tengah Tahun 2012-2016 (jutaan rupiah)

\begin{tabular}{|c|c|c|c|c|}
\hline No. & Tahun & $\begin{array}{c}\text { Target } \\
\text { Anggaran }\end{array}$ & $\begin{array}{c}\text { Realisasi } \\
\text { Anggaran }\end{array}$ & $\begin{array}{c}\text { Pertumbuhannya } \\
\text { (\%) }\end{array}$ \\
\hline 1 & 2012 & 63.875 .689 .108 & 36.085 .703 .274 & 56,00 \\
\hline 2 & 2013 & 64.363 .406 .363 & 74.476 .851 .389 & 115,71 \\
\hline 3 & 2014 & 57.069 .464 .600 & 68.205 .554 .804 & 119,00 \\
\hline 4 & 2015 & 75.938 .620 .000 & 89.128 .201 .927 & 117,37 \\
\hline 5 & 2016 & 81.102 .636 .846 & 89.792 .778 .648 & 110,71 \\
\hline \multicolumn{2}{r|}{ J u m I a h } & $\mathbf{3 4 2 . 3 4 9 . 8 1 6 . 9 1 7}$ & $\mathbf{3 5 7 . 6 8 9 . 0 9 0 . 0 4 2}$ & $\mathbf{5 1 8 , 7 9}$ \\
\hline & Rata-rata & $\mathbf{6 8 . 4 6 9 . 9 6 3 . 3 8 3}$ & $\mathbf{7 1 . 5 3 8 7 . 8 1 8 . 0 0 8}$ & $\mathbf{1 0 3 , 7 5}$ \\
\hline
\end{tabular}

Sumber : Kabupaten Lombok Tengah dalam Angka 2012-2016, diolah.

Berdasarkan data tabel di atas dapat dijelaskan bahwa angka pertumbuhan Pendapatan Lain Yang Syah dilihat dari segi target anggaran dengan realisasi anggaran terhitung sejak tahun 2012 pertumbuhannya sebesar 56,00 persen, tahun 2013 meningkat menjadi sebesar 115,71 persen, tahun 2014 naik menjadi sebesar 119,00 persen, tahun 2015 turun menjadi sebesar 117,37 persen dan tahun 2016 meningkat lagi menjadi sebesar 110,71 persen. Angka pertumbuhan tertinggi terjadi pada tahun 2014 yaitu sebesar 119,00 persen. Angka pertumbuhan rata-rata selama 5 (lima) tahun terhitung sejak tahun 2012-2016 mencapai 103,75 persen.

\section{Perkembangan Produk Domestik Regional Brutto}

Pendapatan Domestik Regional Brutto (PDRB) merupakan seluruh nilai tambah yang diciptakan dari berbagai aktivitas ekonomi di suatu daerah pada priode tertentu (satu tahun).Adapun dasar perhitungan PDB/PDRB sejak tahun 2014 menggunakan tahun dasar 2010 dengan basis SNA 2008.Salah satu implikasi penggunaan SNA 2008 adalah perubahan nominal dan perubahan klasifikasi PDRB dari 9 sektor menjadi 17 katagori. PDRB atas dasar harga berlaku (ADH) Kabupaten
Lombok Tengah tahun 2016 mencapai 16,04 Trilyun rupiah. Angka ini menunjukkan peningkatan sekitar 1,5 Trilyun dari keadaan tahun 2015 yang mencapai 14,49 Trilyun.Jika kita ingin melihat struktur ekonomi suatu daerah dapat dilihat dari kontribusi masingmasing katagori terhadap pembentukan PDRB.Angka PDRB Lombok Tengah menunjukkan bahwa katagori pertanian, kehutanan, dan perikanan memiliki kontribusi terbesar dalam pembentukan PDRB. Sebagai gambaran pada tahun 2016 lebih dari 1/4 (seper-empat) atau 28,35 persen PDRB Lombok Tengah berasal dari katagori pertanian. Meskipun dari tahun ke tahun persentase ini semakin mengecil dengan pergerakan yang relatif 'kecil/halus'.Secara umum menunjukkan perlahan namun pasti kecendrungan usaha sector pertanian semakin menurun/berkurang.Selain itu PDRB atas dasar harga konstan biasanya digunakan untuk melihat pertumbuhan ekonomi di suatu daerah. Dilihat dari segi laju pertumbuhan ekonomi Kabupaten Lombok Tengah pada tahun 2016 mencapai 5,18 persen.

Selanjutnya untuk melihat bagaimana pertumbuhan ekonomi kabupaten Lombok tengah yang dicerminkan melaluiProduk Domestik Regional Brutto (PDRB) berdasarkan harga konstan tahun 2010 (ADHK) dan Produk Domestik Regional Brutto (PDRB) atas dasar 
harga berlaku (ADHB) selama 5 (lima) tahun sejak tahun 2012-2016 akan disajikan pada tabel di bawah ini :

Tabel 8.Pertumbuhan Ekonomi(PDRB) Kabupaten Lombok TengahTahun 2012-2016 (jutaan rupiah)

\begin{tabular}{|c|c|c|c|c|c|}
\hline No. & Tahun & $\begin{array}{c}\text { PDRB Atas } \\
\text { Dasar } \\
\text { Harga Berlaku }\end{array}$ & $\begin{array}{c}\text { PDRB Atas } \\
\text { Dasar } \\
\text { Harga Konstan } \\
\mathbf{2 0 1 0}\end{array}$ & $\begin{array}{c}\text { Pertumbuhan } \\
\text { Atas Dasar } \\
\text { Harga Berlaku } \\
(\mathbf{\%})\end{array}$ & $\begin{array}{c}\text { Pertumbuhan } \\
\text { Atas Dasar } \\
\text { Harga Konstan } \\
\mathbf{2 0 1 0}(\mathbf{\%})\end{array}$ \\
\hline 1 & 2012 & 10.173 .536 & 10.706 .985 & 10,04 & 9,55 \\
\hline 2 & 2013 & 10.721 .723 & 11.531 .845 & 10,53 & 9,79 \\
\hline 3 & 2014 & 11.249 .937 & 12.875 .891 & 11,06 & 9,66 \\
\hline 4 & 2015 & 11.913 .551 & 14.240 .549 & 11,21 & 9,37 \\
\hline 5 & 2016 & 12.535 .284 & 16.044 .443 & 13,95 & 10,91 \\
\hline \multicolumn{2}{|c|}{ J u m I a h } & $\mathbf{5 6 . 5 9 4 . 0 3 1}$ & $\mathbf{6 5 . 3 9 9 . 7 1 3}$ & $\mathbf{5 6 , 7 9}$ & $\mathbf{4 9 , 2 8}$ \\
\hline \multicolumn{2}{|r|}{ Rata-rata } & $\mathbf{1 1 . 3 1 8 . 8 0 6}$ & $\mathbf{1 3 . 0 7 9 . 9 4 2}$ & $\mathbf{1 1 , 3 6}$ & $\mathbf{9 , 8 5}$ \\
\hline
\end{tabular}

Sumber : Kabupaten Lombok Tengah dalam Angka 2012-2016, diolah.

Berdasarkan data tabel di atas dapat dijelaskan bahwa angka pertumbuhan Ekonomi(PDRB) dilihat dari segi PDRB Atas DasarHarga Berlaku dan PDRB Atas DasarHarga Konstan 2010 terhitung sejak tahun 2012 pertumbuhannya sebesar 10,04 persen dan 9,55 persen, tahun 2013 meningkat menjadi sebesar 10,53 persen dan 9,79 persen, tahun 2014 turun menjadi sebesar 11,06 persen dan 9,66 persen, tahun 2015 meningkat menjadi sebesar 11,21 persen dan 9,37 persen dan tahun 2016 menjadi sebesar 13,95 persen dan 10,91 persen. Angka pertumbuhan tertinggi terjadi pada tahun 2016 yaitu sebesar 13,95persen dan 10,91 persen. Angka pertumbuhan ratarata selama 5 (lima) tahun terhitung sejak tahun 2012-2016 mencapai 11,36 persen atas harga berlaku dan 9,85 persen atas harga konstan 2010.

\section{Perkembangan Kontribusi Dana Retrebusi Terhadap PDRB (ADHK)}

Selanjutnya untuk melihat bagaimana realisasi dan pertumbuhan Dana Retrebusi Terhadap PDRB Atas Dasar Harga Konstan Tahun 2010 (ADHK) Lombok Tengah selama 5 (lima) tahun sejak tahun 2012-2016 akan disajikan pada tabel di bawah ini :

Tabel 9. Kontribusi Dana Retrebusi Terhadap Laju Pertumbuhan Ekonomi (PDRB) Atas Dasar Harga Konstan 2010Kabupaten Lombok Tengah Tahun 2012-2016 (jutaan rupiah).

\begin{tabular}{|c|c|c|c|}
\hline Tahun & Dana Retrebusi & $\begin{array}{c}\text { PDRB Atas Dasar } \\
\text { Harga Konstan 10 }\end{array}$ & $\begin{array}{c}\text { Persentase } \\
\text { Kontribusi } \\
\text { (\%) }\end{array}$ \\
\hline 2012 & 1.021 .767 & 10.706 .985 & 9,55 \\
\hline 2013 & 1.129 .526 & 11.531 .845 & 9,79 \\
\hline 2014 & 1.243 .781 & 12.875 .891 & 9,66 \\
\hline 2015 & 1.335 .017 & 14.240 .549 & 9,37 \\
\hline 2016 & 1.749 .586 & 16.044 .443 & 10,91 \\
\hline Jumlah & $\mathbf{6 . 4 7 9 . 6 7 7}$ & $\mathbf{6 5 . 3 9 9 . 7 1 3}$ & $\mathbf{4 9 , 2 8}$ \\
\hline Rata-rata & $\mathbf{1 . 2 9 5 . 9 3 5}$ & $\mathbf{1 3 . 0 7 9 . 9 4 2}$ & $\mathbf{9 , 8 5}$ \\
\hline
\end{tabular}

Sumber : Kabupaten Lombok Tengah dalam Angka 2012-2016, diolah.

Berdasarkan data tabel di atas dapat dijelaskan bahwa angka pertumbuhan Kontribusi Dana Retrebusi Terhadap Laju Pertumbuhan Ekonomi (PDRB) Atas Dasar Harga Konstan 2010Kabupaten Lombok
Tengah Tahun 2012-2016sebagai berikut :terhitung sejak tahun 2012 pertumbuhankontribusinya sebesar 9,55 persen, tahun 2013 meningkat menjadi sebesar 9,79 persen, tahun 2014 turun 
menjadi sebesar 9,66 persen, tahun 2015 turun lagi menjadi sebesar 9,37 persen dan tahun 2016 meningkat lagi menjadi sebesar 10,91 persen. Angka pertumbuhan tertinggi terjadi pada tahun 2016 yaitu sebesar 10,91 persen. Angka pertumbuhan rata-rata selama 5 (lima) tahun terhitung sejak tahun 20122016 mencapai 9,85 persen.

\section{Perkembangan Kontribusi Dana Retrebusi} Terhadap PDRB (ADHB)

Selanjutnya untuk melihat bagaimana pertumbuhan Kontribusi Dana Retrebusi Terhadap PDRB Atas Dasar Harga Berlaku (ADHB) Lombok Tengah selama 5 (lima) tahun sejak tahun 2012-2016 akan disajikan pada tabel dibawah ini:

Tabel 10. Kontribusi Dana Retrebusi Terhadap Laju Pertumbuhan Ekonomi(PDRB) Atas Dasar Harga Berlaku Kabupaten Lombok Tengah Tahun 2012-2016 (jutaan rupiah).

\begin{tabular}{|c|c|c|c|}
\hline Tahun & Dana Retrebusi & $\begin{array}{c}\text { PDRB Atas Dasar } \\
\text { Harga Berlaku }\end{array}$ & $\begin{array}{c}\text { Persentase } \\
\text { Kontribusi } \\
\text { (\%) }\end{array}$ \\
\hline 2012 & 1.021 .767 & 10.173 .536 & 10,04 \\
\hline 2013 & 1.129 .526 & 10.721 .723 & 10,53 \\
\hline 2014 & 1.243 .781 & 11.249 .937 & 11,06 \\
\hline 2015 & 1.335 .017 & 11.913 .551 & 11,21 \\
\hline 2016 & 1.749 .586 & 12.535 .284 & 13,95 \\
\hline Jumlah & $\mathbf{6 . 4 7 9 . 6 7 7}$ & $\mathbf{5 6 . 5 9 4 . 0 3 1}$ & $\mathbf{5 6 , 7 9}$ \\
\hline Rata-rata & $\mathbf{1 . 2 9 5 . 9 3 5}$ & $\mathbf{1 1 . 3 1 8 . 8 0 6}$ & $\mathbf{1 1 , 3 6}$ \\
\hline
\end{tabular}

Sumber :Kabupaten Lombok Tengah dalam Angka 2012-2016, diolah.

Berdasarkan data tabel di atas dapat dijelaskan bahwa angka pertumbuhan Kontribusi Dana Retrebusi Terhadap Laju Pertumbuhan Ekonomi (PDRB) Atas Dasar Harga Berlaku Kabupaten Lombok Tengah Tahun 2012-2016sebagai berikut :terhitung sejak tahun 2012 pertumbuhankontribusinya sebesar 10,04 persen, tahun 2013 meningkat menjadi sebesar 10,53 persen, tahun 2014 meningkat menjadi sebesar 11,06 persen, tahun 2015 meningkat lagi menjadi sebesar 11,21 persen dan tahun 2016 meningkat lagi menjadi sebesar 13,95 persen. Angka pertumbuhan tertinggi terjadi pada tahun 2016 yaitu sebesar 13,95 persen. Angka pertumbuhan rata-rata selama 5 (lima) tahun terhitung sejak tahun 2012-2016 mencapai 11,36 persen.

\section{Kesimpulan}

\section{KESIMPULAN DAN SARAN}

1. Proporsi pengalokasian dana pembangunan terhadap laju percepatan pertumbuhan ekonomi Kabupaten Lombok Tengahterhitung sejak Tahun 2012-2016 cukup besar.
2. Proporsi pengalokasian dana rutin terhadap laju percepatan pertumbuhan

3. ekonomi Kabupaten Lombok Tengahterhitung sejak Tahun 2012-2016 sangat besar

4. Kontribusi alokasi dana pembangunan dan alokasi dana rutin terhadap daya doronglaju percepatan pertumbuhan ekonomi Kabupaten Lombok Tengahterhitung sejak Tahun 2012-2016 tidak significan.

\section{Saran}

1. Mengingat besarnya peranan dana perimbangan baik yang bersumber dari dana alokasi umum (DAU) maupun yang bersumber dari dana alokasi khusus (DAK) terhadap pendapatan daerah dan pertumbuhan ekonomi (PDRB), maka pemerintah kabupaten Lombok Tengah kedepannya tidak dapat secara terus menerus menggantungkan sumber pendapatan daerahnya dari dana perimbangan tersebut. Oleh karenanya mulai saat ini hendaknya pemerintah daerah harus sudah mulai berpikir tentang penggalian potensi sumber-sumber pendanaan dan pendapatan daerah lainnya agar tidak terlalu mengandalkan dana perimbangan sebagai sumber dana 
satu-satunya untuk melaksanakan pembangunan di berbagai sektor ekonomi.

2. Disamping optimalisasi penggalian potensi sumber dana, pemerintah kabupaten Lombok Tengah hendaknya dapat melakukan intensifikasi perpajakan melalui penerapan efektivitas dan efisiensi sistem perpajakan serta pemberian reward and fanishment terhadap petugas pajak yang ada.

\section{DAFTAR PUSTAKA}

Arsyad Lincolind, Ekonomi Pembangunan, Sekolah Tinggi Ilmu Ekonomi YKPN, Yogyakarta, 2004.

Arsyad, L. 2010. Pengantar Perencanaan dan Pembangunan Daerah. Edisi Pertama, Yogyakarta, BPFE

Badan Pusat Statistik. Nusa Tenggara Barat Dalam Angka Tahun 2012 . Nusa Tenggara Barat Dalam Angka Tahun 2014 . Nusa Tenggara Barat Dalam Angka Tahun 2016

Bali Bisnis.Com.diunduh tanggal 21-9-2017.

Dendi Asita, dkk. Perencanaan Strategi Partisipatif Pengembangan Ekonomi Lokal Dalam Bingakai Ekonomi Kerakyatan. P2k Unram. 2010..

Irwan dan M. Suparmoko, 1988. Ekonomi Pembangunan.

Jhingan, M.L, 2010. Ekonomi Pembangunan Dan Perencanaan. Ed. Ke 13. Jakarta, PT. Raja Grafindo Persada.

Kuncoro, M.; 2010.Dasar-Dasar Ekonomika Pembangunan. Edisi 5, Yogyakarta, UPP STIM YKPN.

Nazir, Moh, 2011. Metode Penelitian, Ed. Ke 7, Bogor, Ghalia Indonesia.

Nehen, Ketut, Perekonomian Indonesia, Udayana University Press, Denpasar, 2012.

Nurmayanti, Dian Anggraini, Distribusi Pendapatan dan Kemiskinan di Indonesia, diananggraini.blogspot.com.2013/05. diunduh tanggal 21 September 2017.

Sukirno, Sadono, 2013. Ekonomi Pembangunan. Proses, Masalah Dan Dasar Kebijakan. Edisi Kedua. Jakarta, Kencana Pranada Media Group.

Todaro, Michael P. 2011. Pembangunan Ekonomi. Ed. Ke - 11. Jakarta: Erlangga

Widodo, Tri, 2006. Perencanaan Pembangunan. Cetakan Pertama, UPP STIM YKPN Yogyakarta.

Widodo, Hg. Suseno Triyanto, 1990. Indikator Ekonomi. Yogyakarta, Kanisius.

www. Bps.go.id/link/ginirasio provinsi 2002-2007 